Original Research

\title{
Diversifying Tourism in Municipalities within Impact Areas of National Parks
}

\author{
Konrad Podawca*, Agata Pawlat-Zawrzykraj** \\ Warsaw University of Life Sciences, Faculty of Civil and Environmental Engineering, \\ Department of Civil Engineering, Warsaw, Poland
}

Received: 6 September 2017

Accepted: 22 October 2017

\begin{abstract}
The objective of this work was to present the tourism potential (PT) and tourism attractiveness (AT) of municipalities located in the impact areas of Polish national parks. Moreover, the classification of the municipalities based on the so-called tourism utilization rate has been elaborated. According to the analysis, the percentage of the municipalities of each type in terms of TP and TA is very similar only in the group consisting of the best municipalities ( $4.9 \% \mathrm{TP} ; 5.8 \% \mathrm{TA})$. In the remaining cases, the distribution is disproportionate. Municipalities with a medium tourism potential account for $78.6 \%$, while administrative units with a low TP $-16.5 \%$. The inverse situation can be observed in the case of the TA indicator. There are $17,5 \%$ of municipalities with medium tourism offer in relation to the most numerous units with small TA (76.7\%. of the municipalities). The municipalities take advantage of their natural resources and tourist virtues to various extents. $13.6 \%$ of the analysed administrative units have implemented their tourism potential very well, which confirms that it can be regarded as a mean for the local economic development. Unfortunately, the number of municipalities where the existing conditions for leisure activities and recreation are not used in a satisfactory way is comparable (15.5\%). The most numerous group is comprised of local administrative units that use their tourism potential at a medium level $(36,9 \%)$. At the same time, the fact that a significant share of municipalities benefit well from the available resources (34\%) should be considered positive.
\end{abstract}

Keywords: tourism, municipality, national park, tourism potential

\section{Introduction}

It is rather obvious that natural and cultural values are the main factors determining tourists' choices for holiday destinations [1-2]. Therefore, many countries use National Parks (NPs) to promote tourism [3]. Quoting

*e-mail: agata_pawlat_zawrzykraj@sggw.pl,

**e-mail: konrad_podawca@sggw.pl
Stokke et al. [4], "'National park' is an internationally understood label, which conjures up visions of beautiful places, high levels of visitor facilities, and general attractiveness." Research conducted in Norway's national parks showed that for $40 \%$ of foreign tourists, the arrival was directly related to the status of the areas as national parks [4]. An Australian report on Queensland NPs states that half of the tourists would not have come if the areas were not national parks [5]. Similar conclusions can be found in publications concerning Polish NPs [6-7]. 
Tourism's impact on the economics of areas located within the borders of NPs or in their immediate vicinity has been the subject of numerous publications [8-12]. This impact depends on external factors that parks and local authorities have no direct influence on, as well as internal ones - mostly regarding the attractiveness of the park itself. The national governments' nature conservation policy, which has a major impact on spatial planning and land-use management of NP municipalities, also is a significant factor. Therefore, inhabitants often perceive it as restrictive and interfering with private interests through various legal, economic and administrative constraints [11]. It is not surprising that the benefits from the tourist influx are often recognized by local communities as a form of compensation for the loss of potential benefits or opportunities. They expect that national parks, apart from environmental protection tasks, will also stimulate local, social, and economic development [12]. Research conducted by Zawlińska and Mika [11] concerning municipalities administratively associated with national parks in Poland, confirms that the assessment of the impact of parks on the present and future economic situation of the examined municipalities is varied. A positive influence in the future is anticipated by $24 \%$ of respondents, and negative by $11 \%$. Among the most important benefits from a park in the studied municipalities, tourism and related services $(76 \%)$ as well as the promotion of the community $(25 \%)$ were indicated by respondents. The impact of a park on the state of the natural environment $(40 \%)$ and growing ecological awareness were also highly evaluated. It is interesting to see that the advantages of the park's operation are more visible and higher rated at the regional level rather than at the local one [11, 13-14].

The favourable economic and educational impact of tourism in NPs is inevitably accompanied by negative phenomena $[9,13]$. Tourism may conflict with ecological goals and lead to strong disagreement over the use of parks [13]. To quote Ceballos-Lascuráin et al. [15], "The guiding principle for the development of tourism in national parks is to manage the natural and human resources so as to maximize visitor enjoyment while minimising the negative impacts of tourism development." The potential negative impact on the protection of NPs requires appropriate landuse planning and management [16]. The basis for these activities is a proper evaluation of the number of visitors, their motives, demand factors, and park characteristics. Factors that strongly influence the tourist attractiveness of an NP, and thus the number of visitors, are not only the environmental factors, but also social ones such as: quality and variety of the program, quality of the recreation facilities and standard of accommodation, as well as accessibility and distance from the population [10, 17-18]. In their research on Polish national parks, Rusielik and Zbareszewski [19] show that a significant measure of the parks' attractiveness is also their educational activity (events, educational trails, popular science publications). Moreover, currently it is recognized that the so-called "informational accessibility" (good websites and good social media exposure) is an important factor stimulating tourism development in NPs, which raises awareness of the protected area and the whole region [3]. The classification of Polish national parks by the intensity of tourism was studied by Graja [6] and Liszewski [20]. The latter considered the density of tourist routes and the number of tourists on routes to be a key measure. In the study, four types of national parks were distinguished due to the intensity of tourism utilisation: very high rate (Karkonosze NP), high rate (7 NPs: Wielkopolska, Tatra, Pieniny, Góry Stołowe, Wolin, Ojców, Kampinos), medium rate (11 NPs: Biebrza, Wigry, Słowiński, Świętokrzyski, Drawa, Bory Tucholskie, Babia-Góra, Roztocze, Gorce, Biebrza, Białowieża) and low rate (4 NPs: Magura, Ujście Warty, Polesie, Narew).

It follows from the above that tourism in national parks is a complex issue. For this reason, it should be of interest to park authorities as well as to local authorities and residents. There is a strong need for further enhancement of knowledge about the existing factors affecting the development of tourism in national parks and the utilization rate of the available resources.

The objective of this work was to present the tourist potential and tourist attractiveness of municipalities located in the impact areas of Polish national parks. Three general theses have been formulated:

- Tourism development of the analysed municipalities depends on the potential of their natural and cultural environments.

- There is a significant spatial diversification of the tourist attractiveness of municipalities located in the impact area of national parks.

- Many municipalities still do not fully utilize existing tourism potential.

\section{Material and Methods}

\section{Study Area}

Poland has 23 National Parks. The oldest one, Bialowieża, was established in 1947 and the youngest, Warta Ujście, in 2001. The smallest, Ojcowski, occupies $21.45 \mathrm{~km}^{2}$ while the largest, Biebrzański, sits on $592.23 \mathrm{~km}^{2}$. Parks with a surface area of $50-100 \mathrm{~km}^{2}$ dominate in Poland (there are 9). The parks comprise areas that are very diversified in terms of landscape (8 mountain, 5 lowlands, 5 lake districts, 3 uplands, 2 seashore). Most of them are located in poorly urbanized areas of the country. Only two are in the immediate vicinity of urban agglomerations (Kampinoski on the outskirts of Warsaw and Wielkopolski near Poznań) and a few partly lie within the administrative boundaries of towns (Karkonosze in Jelenia Góra and Wolin in Świnoujście). 
The number of tourists visiting Polish national parks is growing slowly. In 2014 [21] it amounted to $117,995,000$. In 2001 it was $103,450,000$, in 2005 105,250,000, and in 2007 109,920,000. Spatial distribution of parks with the largest number of tourists is uneven. Out of the 5 parks visited by more than one million tourists, 2 are located in mountains (Tatra - 3.1 million and Karkonosze - 2 million), one at the seaside (Wolin - 1.5 million) and 2 (Wielkopolska - 1.2 millions and Kampinos -1 million) in zones under the direct influence of large cities - combining the tourist function with suburban recreation.

The preliminary survey covered 114 (4.5\%) of the 2,478 municipalities in Poland. These are the administrative units that have been granted natural protection as an NP. In terms of area, the largest group $(43 \%)$ of the municipalities is those where the area of an NP in their total area is less than $10 \%$. A similar number of municipalities $(37 \%)$ make up a group with a share of $10-30 \%$ of their area with NPs, whereas the share of $30-50 \%$ and more than $50 \%$ corresponds to the smallest groups (10\% each).

Examples of municipalities in which the area of a national park is significant are: Zwierzyniec (52\%) in Roztocze NP, Karpacz (53\%) in Karkonosze NP, Goniądz (59\%) in Biebrza NP, Smołdzino (57\%) in Słowiński NP, Zakopane (60\%) and Kościelisko $(60 \%)$ in Tatra NP, Krempna (62\%) in Magurski PN, Międzyzdroje (63\%) in Woliński NP, and Leoncin (62\%) and Izabelin (86\%) in Kampinos NP [22].

Out of all the municipalities that have national parks within their boundaries, 11 urban units have been eliminated, concluding that the development of tourism in these areas is driven by some additional factors and the obtained indicators may disturb the correct picture of other units. Finally, the spatial scope of the study covered 103 rural and urban-rural municipalities.

\section{Methods}

The following study methods have been used:

- Filtering data collected from the local data bank [23] for 2014 in the fields of tourism, territorial division, state and environmental protection, population, culture and arts, and transport and communication.

- Designating variables for the selected features to achieve their comparability.

- Normalizing variables to determine their significance in the tourism potential and attractiveness of the municipality.

- Designating synthetic indicators (tourism attractiveness - TA and tourism potential - TP) and identifying the correlation between them

The selection of the analysed variables was based on the statement presented in the introduction that tourist development in a given area is mainly determined by cultural and natural values, tourism infrastructure, and transport accessibility. The research conducted by Borys [24], Chudy-Hyski [25], Włodarczyk [26],
Brzezińska-Wójcik and Świeca [27] ZiarnickaWojtaszek and Zawora [28] - supplemented by studies made for Polish National Parks [20] - helped determine the indicators that affect tourism attractiveness and potential of the studied areas. Therefore, the following characteristics and variables were used to assess the level of tourism potential:

- Surface area of legally protected areas per total area of the municipality $-\mathrm{x}_{1}$.

- Forest area per total area of the municipality $-x_{2}$.

- Area of surface water per total area of the municipality $-\mathrm{x}_{3}$.

- Area of recreational areas per $10 \mathrm{~km}^{2}-\mathrm{x}_{4}$.

- The number of natural monuments per $10 \mathrm{~km}^{2}-\mathrm{x}_{5}$.

- The number of cultural monuments per $10 \mathrm{~km}^{2}-\mathrm{x}_{6}$.

- Communication (transport) area per total area of the municipality $-\mathrm{x}_{7}$.

The indicators listed above should appropriately influence the number of tourists visiting an area, the development of tourist accommodations, tourism and recreation infrastructure, and cultural and outdoor events. Therefore, the following variables reflecting the tourist use of the area were considered in the case of tourism attractiveness:

- The number of tourists using the accommodation per total area of the municipality $-\mathrm{x}_{8}$.

- The number of overnight stays per total area of the municipality $-\mathrm{x}_{9}$.

- The number of tourist accommodation sites per 10 $\mathrm{km}^{2}-\mathrm{x}_{10}$.

- The number of beds per $10 \mathrm{~km}^{2}-\mathrm{x}_{11}$.

- The number of sports and recreational facilities per number of tourist accommodation sites $-\mathrm{x}_{12}$.

- The length of bicycle paths per $10 \mathrm{~km}^{2}-\mathrm{x}_{11}$.

- The number of events organised by culture centres per 1,000 citizens $-x_{14}$.

The next stage of the work on the variables was their normalization, which allowed us to convert the values of variables expressed in different units into a comparable form. This was achieved by using the methods developed by Strahl [29] and Walesiak [30]. Due to the fact that all variables have a stimulant status, the following formula (1) for the normalization has been used:

$$
z_{i j}=\frac{x_{i j}}{\max x_{i j}}
$$

...where $\mathrm{x}_{i j}$ is the value of $\mathrm{j}^{\text {th }}$ variable in $\mathrm{i}^{\text {th }}$ municipality, $\max x_{i j}$ is the maximum value of $\mathrm{j}^{\text {th }}$ variable, and $z_{i j}$ is the normalized value of $x_{i j}$.

A synthetic picture of the attractiveness and tourism potential of municipalities was obtained by aggregating data using the non-model method. Formula (2) produces values ranging from 0 to 1 :

$$
W_{T A(T P)}=\frac{1}{n} \sum_{j=1}^{n} z_{i j}
$$


...where $W_{T A(T P)}$ is the synthetic indicator of tourism attractiveness (tourism potential) of municipalities; $j$ $-1,2, \ldots, \mathrm{n}$; and $n$ is the number of included indicators.

The last stage of the work was the classification of the municipalities based on the so-called tourism utilization rate (3).

$$
W_{T U}=\frac{W_{T A}}{W_{T P}}
$$

In order to diversify the municipalities and to present their spatial distribution, they have been divided into certain types and groups according to the obtained synthetic indicators. For indicators $\mathrm{W}_{\mathrm{TP}}$ and $\mathrm{W}_{\mathrm{TA}}$, equal ranges have been used.

According to tourism attractiveness, the administrative units have been assigned to one of the following three types:

- Type A - with a high tourism attractiveness TA, for which the value of the synthetic indicator of tourism attractiveness $\mathrm{W}_{\mathrm{TA}}$ exceeds $66 \%$ of the maximum value, i.e., more than 0.333 .

- Type B - with a medium tourism attractiveness TA, for which the value of the synthetic indicator of tourism attractiveness $\mathrm{W}_{\mathrm{TA}}$ is in the range $<0.167 ; 0.333>$.

- Type C - with a low tourism attractiveness TA, for which the value of the synthetic indicator of tourism attractiveness $\mathrm{W}_{\mathrm{TA}}$ is less than $1 / 3$ of the maximum value, i.e., less than 0.167 .

Similar types have been indicated concerning tourism potential:

- Type 1 - a high tourism potential TP, for which the value of the synthetic indicator of tourism potential $\mathrm{W}_{\mathrm{TP}}$ exceeds $66 \%$ of the maximum value, i.e., more than 0.379 .

- Type 2-a medium tourism potential TP, for which the value of the synthetic indicator of tourism potential $\mathrm{W}_{\mathrm{TP}}$ is in the range $<0.189 ; 0.379>$.

- Type 3 - a low tourism potential TP, for which the value of the synthetic indicator of tourism potential $\mathrm{W}_{\mathrm{TP}}$ is less than $1 / 3$ of the maximum value, i.e., less than 0.189 .

In the case of the tourism utilization rate $\mathrm{W}_{\mathrm{TU}}$, it has been decided to set up 4 groups of municipalities on the basis of the standard deviation (Fig. 1):

- Group I - municipalities exploiting the existing potential very well, for which the value of the synthetic indicator exceeds the sum of the average value and the standard deviation $\mathrm{W}_{\mathrm{TU}}>\mathrm{X}_{\mathrm{TU}}+\mathrm{S}_{\mathrm{TU}}$, i.e., 0.777 .

- Group II - municipalities exploiting the existing potential well, for which $\mathrm{X}_{\mathrm{TU}}+\mathrm{S}_{\mathrm{TU}} \leq \mathrm{W}_{\mathrm{TU}} \geq \mathrm{X}_{\mathrm{TU}}$, i.e., in the range $<0.465-0.777>$.

- Group III - municipalities exploiting the existing potential on a medium-level, for which the value of $\mathrm{W}_{\mathrm{WU}}$ meets the condition $\mathrm{X}_{\mathrm{TU}}<\mathrm{W}_{\mathrm{TU}} \geq \mathrm{X}_{\mathrm{TU}}-\mathrm{S}_{\mathrm{TU}}$, i.e., in the range $<0.153 ; 0.465)$.

- Group IV - municipalities exploiting the existing potential poorly, for which the value of the synthetic indicator meets the condition $\mathrm{W}_{\mathrm{TU}}<\mathrm{X}_{\mathrm{TU}}-\mathrm{S}_{\mathrm{TU}}$, i.e., less than 0.153 .

\section{Results}

A detailed tabular listing of the calculated variables of tourism potential and tourist use, results of their normalization for the analysed municipalities, as well as the values of synthetic indicators of tourism potential $\left(\mathrm{W}_{\mathrm{TP}}\right)$, tourism attractiveness $\left(\mathrm{W}_{\mathrm{TA}}\right)$, and tourism utilization rate $\left(\mathrm{W}_{\mathrm{TU}}\right)$, are presented in Tables 1-2.

In order to obtain a synthetic picture of the diversity of municipalities in terms of their tourism potential, attractiveness, and utilization, a categorization of the municipalities has been developed. Table 3 shows the numerical distribution of municipalities in the classified types and groups.

The largest set of municipalities are those administrative units with a low tourism attractiveness and a medium potential using it at a medium level: Słońsk (I ${ }^{1}$, Witnica (I), Lipsk (IV), Cisna (V), Lutowiska (V), Drawno (VII), Krzyż Wielkopolski (VII), Niedźwiedź (VIII), Nowy Targ (VIII), Lewin Kłodzki (IX), Czosnów (X), Łomianki (X), Dębowiec (XII), Nowy Żmigród (XII), Osiek Jasielski (XII), Choroszcz (XIII), Łapy (XIII), Suraż (XIII), Turośń Kościelna (XIII), Skała (XIV), Krościenko nad Dunajcem (XV), Sosnowica (XVI), Zwierzyniec (XVII), Główczyce (XVIII), Smołdzino (XVIII), Bieliny (XIX), Łączna (XIX), Nowa Słupia (XIX), Mosina (XXI), and Giby (XXII). The above group of municipalities is complimented with those units with a low TP (Dąbrowa Białostocka - IV, Grajewo - IV, Radziłów - IV, Trzcianne - IV, Wizna - IV, SokołyXIII) or high TP (Sękowa - XII).

The second group includes municipalities with low tourism attractiveness and medium tourism potential that is used on a good level: Górzyca (I), Zawoja (II), Rajgród (IV), Chojnice (VI), Człopa (VII), Tuczno (VII), Kamienica (VIII), Mszana Dolna (VIII), Szczytna (IX), Leszno (X), Stare Babice (X), Tomaszów Mazowiecki (X), Krempna (XII), Tykocin (XIII), Jerzmanowice-Przeginia (XIV), Stary Brus (XVI), Urszulin (XVI), Bodzentyn (XIX), Nowinka (XXII), Suwałki (XXII), and Wolin (XXIII).

A few but very extreme cases are municipalities:

- With high tourism attractiveness based on high tourism potential, which is also very well utilised (Podgórzyn - XI, Szczawnica - XV, Międzyzdroje - XXIII) or well utilised (Ustka - XVIII, Bukowina Tatrzańska - XX, Poronin - XX).

- With low tourism attractiveness based on low tourism potential, but very well utilised (Zamość - XVII) or well utilised (Jaświły - IV, Sułoszowa - XIV, Ludwin - XVI, Suchowola - IV).

Number of the NP according to Table 1 


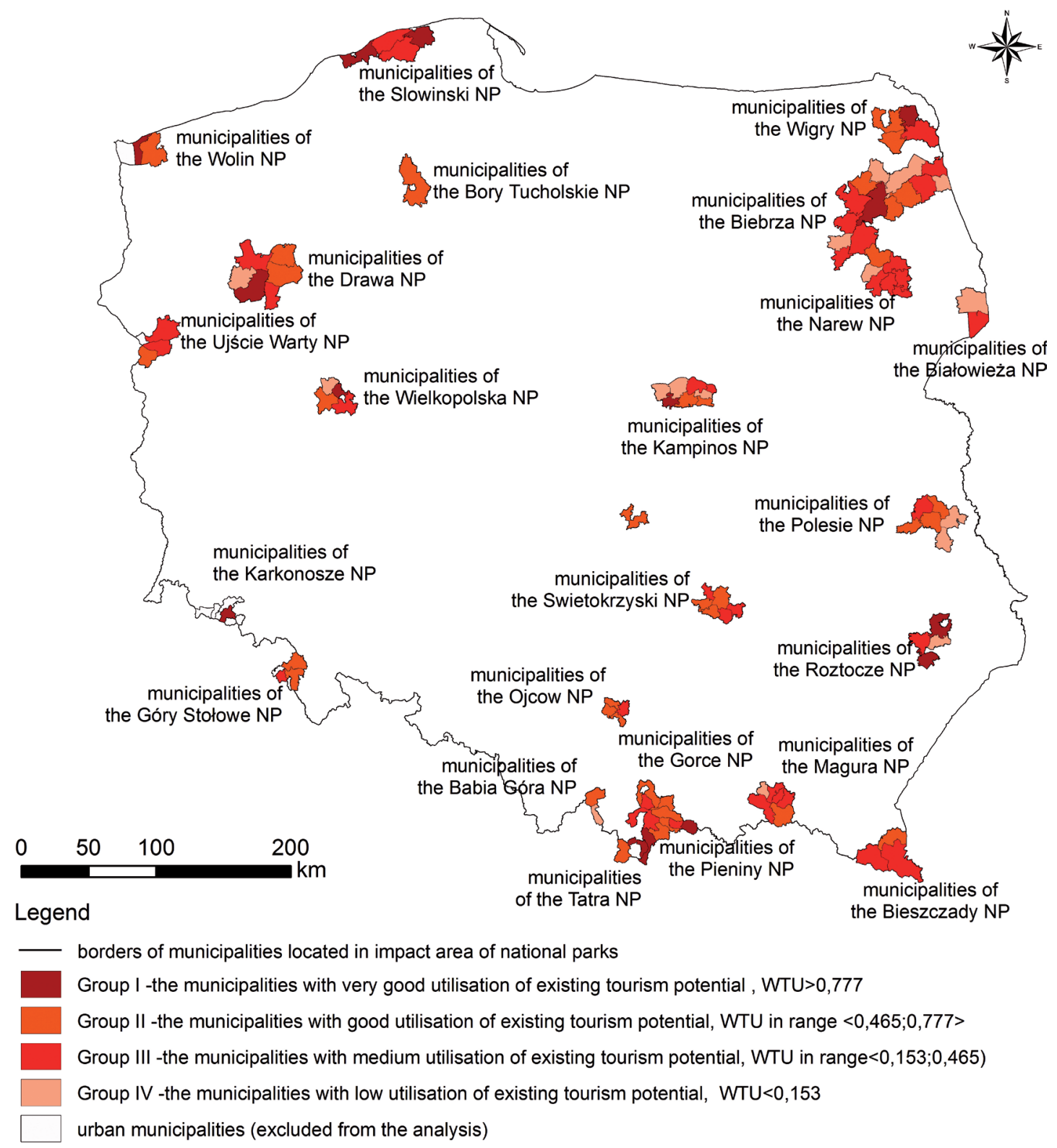

Fig. 1. Spatial distribution of municipality types in terms of tourism utilization rate (by the authors).

- With high TP and medium TA, which has achieved a medium utilisation rate (Białowieża - III).

There is also a group of municipalities where tourism attractiveness is zero due to the lack of (according to BDL) accommodation facilities and tourism infrastructure. In these cases, the calculation outcomes might be unreliable. The problem concerns 5 municipalities with a low TP (Jedwabne - IV, Kobylin - Borzymy - XIII, Wierzbica - XVI, Adamów - XVII, and Nowy Dwór - IV) and 5 units with a medium TP (Bierzwnik - VII, Brochów - X, Izabelin - X, Lipinki XII, and Hańsk - XVI).

Slightly better results in terms of tourism utilisation rate in the case of a low or medium TP have been achieved in 6 municipalities: Bargłów Kościelny (IV), Lipnica Wielka (II), Narewka (III), Sztabin (IV), Leoncin (X), and Dopiewo (XXI).
A favourable situation is observed in the administrative units with a medium TP and a medium TA that are utilised to a very large extent (Goniądz IV, Dobiegniew - VII, Kampinos - X, Józefów - XVII, Wicko - XVIII, Krasnopol - XXII, and Komorniki $\mathrm{XXI}$ ) or to a large extent (Czarna - V, Ochotnica Dolna - VIII, Radków - IX, Wielka Wieś - XIV, Czorsztyn XV, Łapsze Niżne -XV-, Górno - XIX, Masłów - XIX, Kościelisko - XX, and Stęszew - XX).

\section{Discussion and Conclusions}

According to the analysis, the percentage of the municipalities of each type in terms of TP and TA is very similar only in the group consisting of the best municipalities $(4.9 \% \mathrm{TP} ; 5.8 \% \mathrm{TA})$. In the remaining 


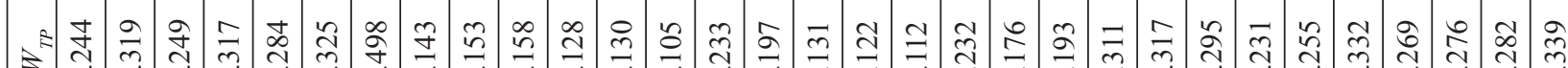

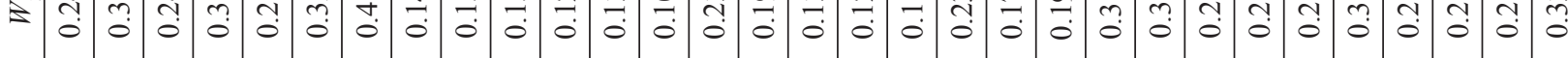

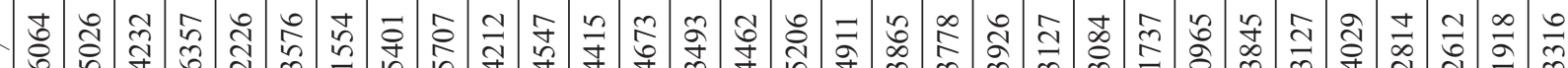

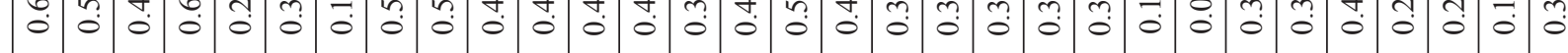

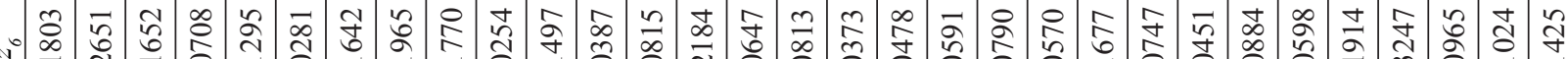

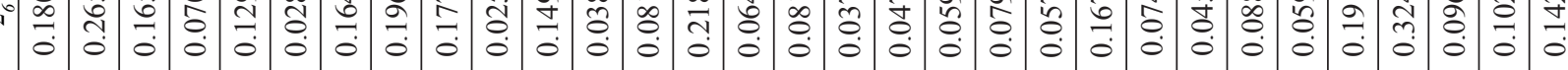

N

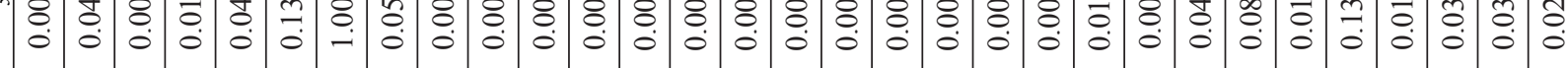

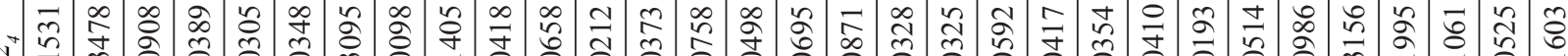

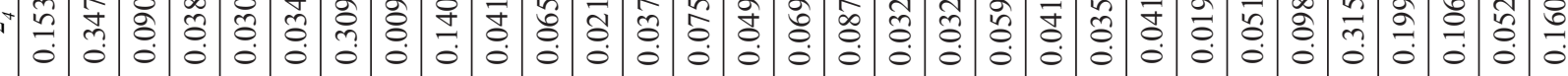

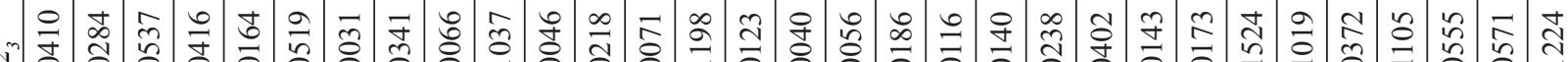

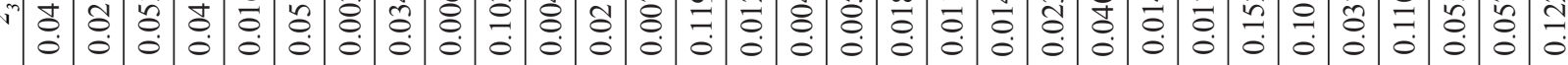

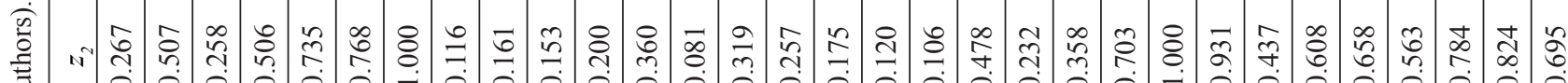

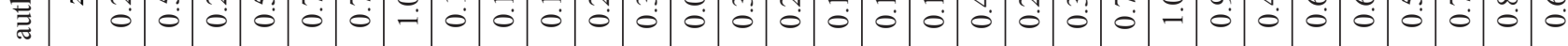

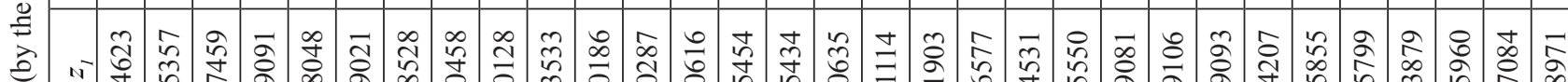

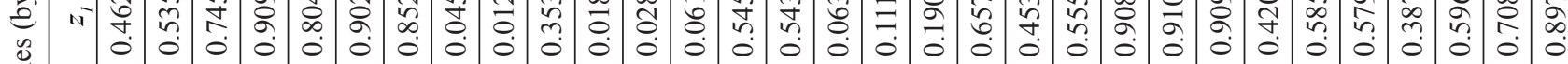
需

బิ

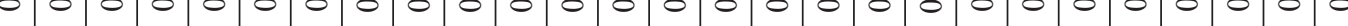

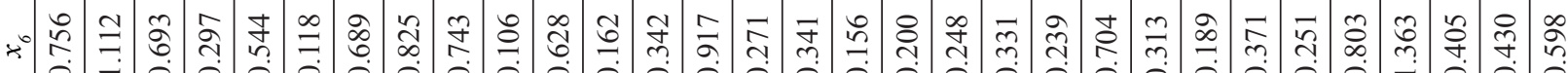

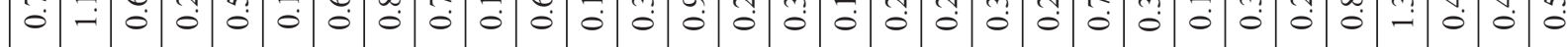

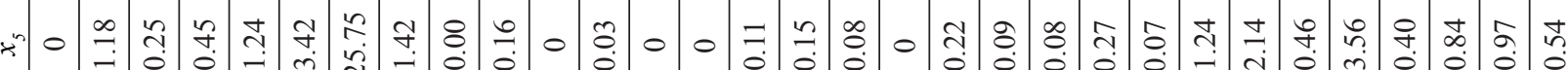

.

ヶ $\stackrel{2}{\circ}$ 羔

:

:

尝

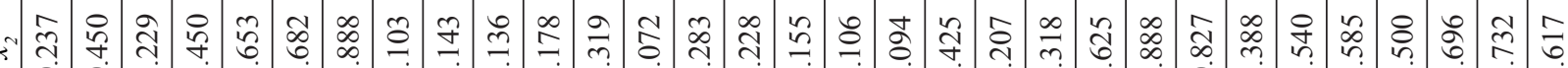

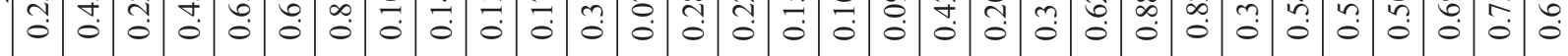

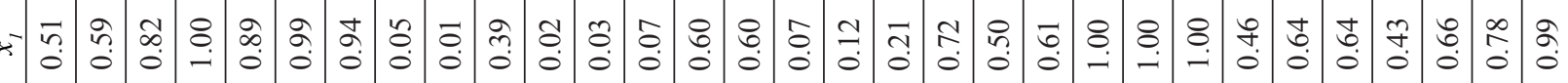

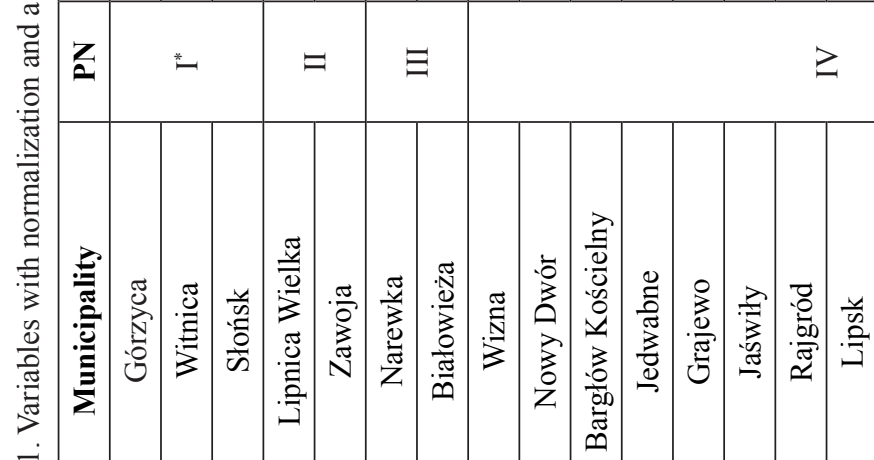
离

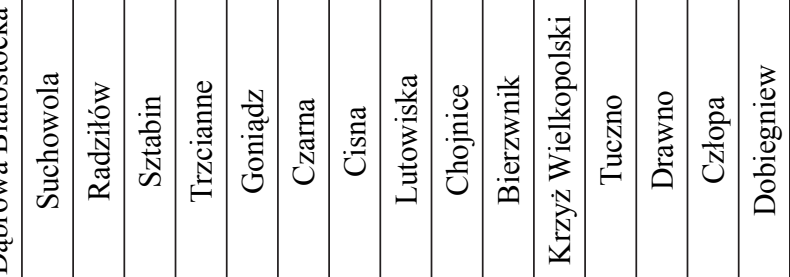




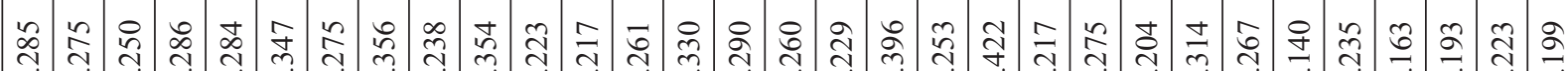
స̂.

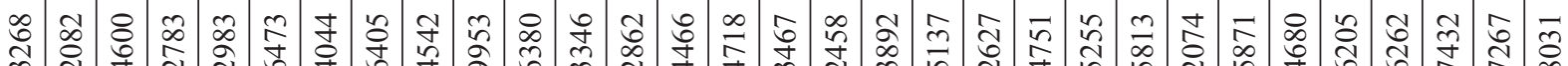

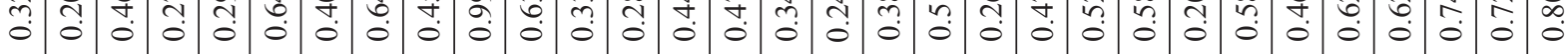

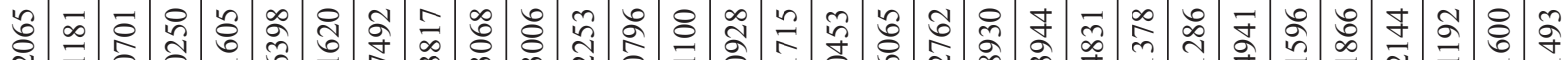

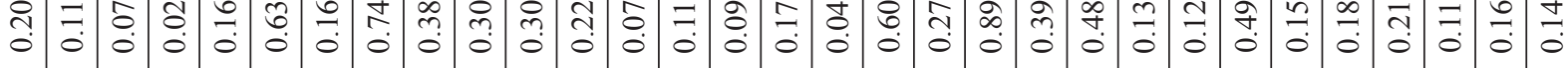

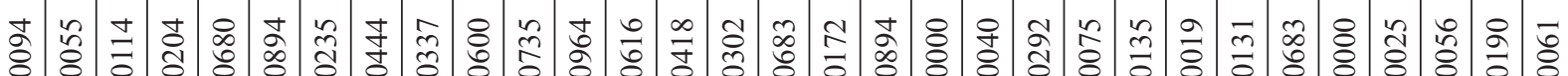

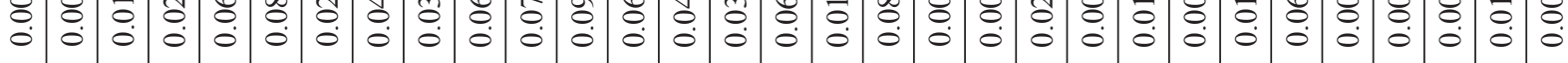

官 $\delta$ o

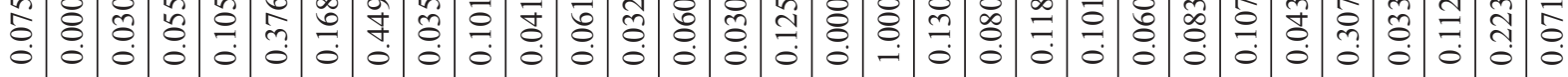

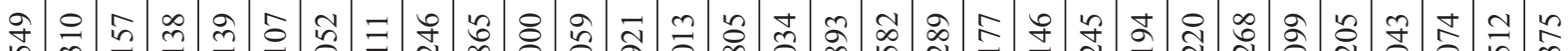

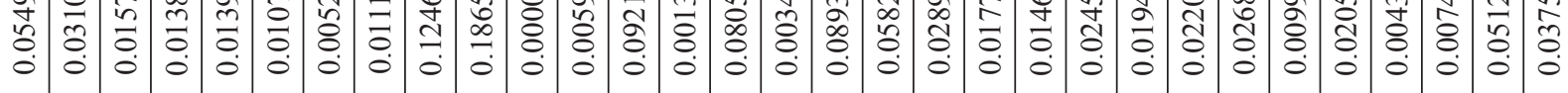

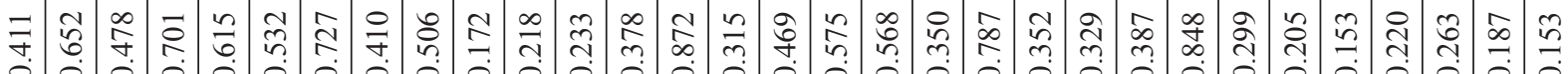

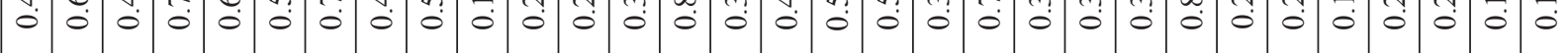

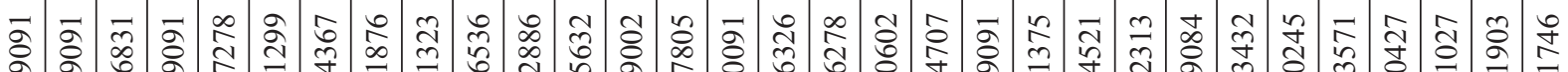

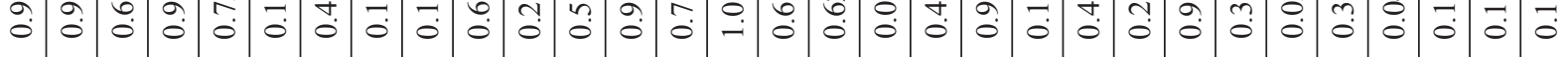

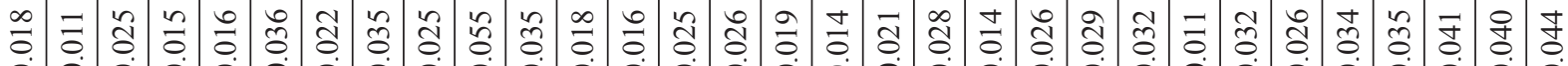

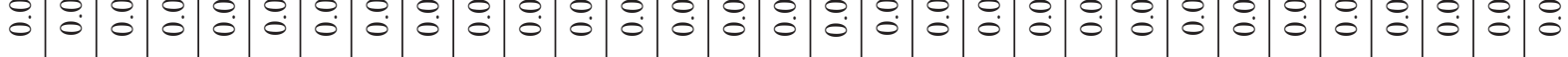

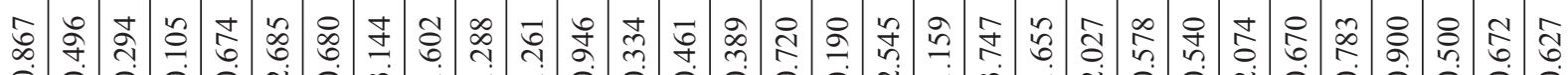
:

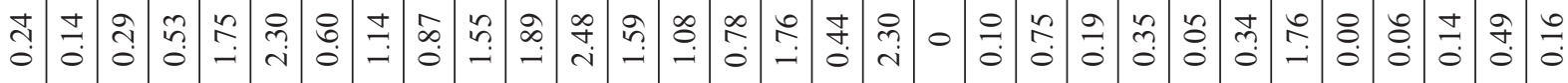

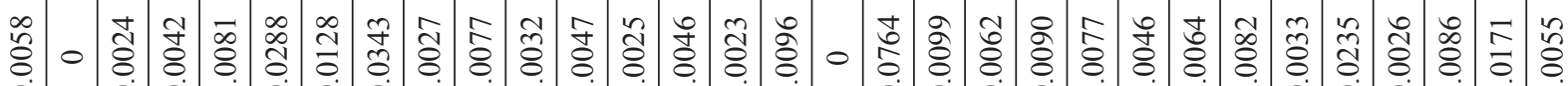

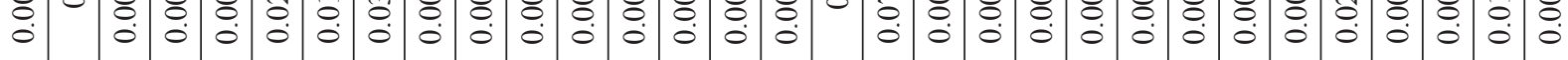

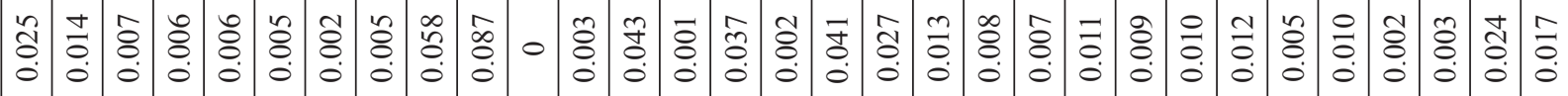

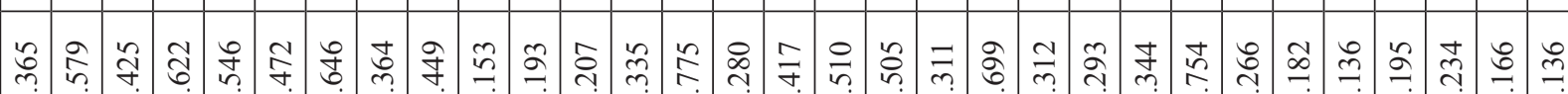

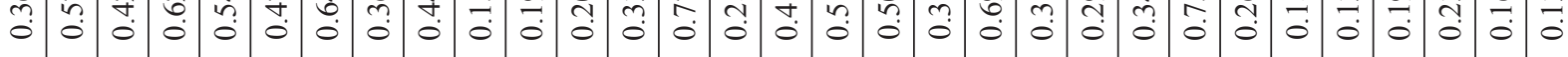

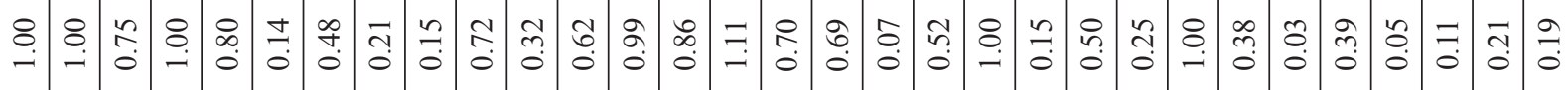

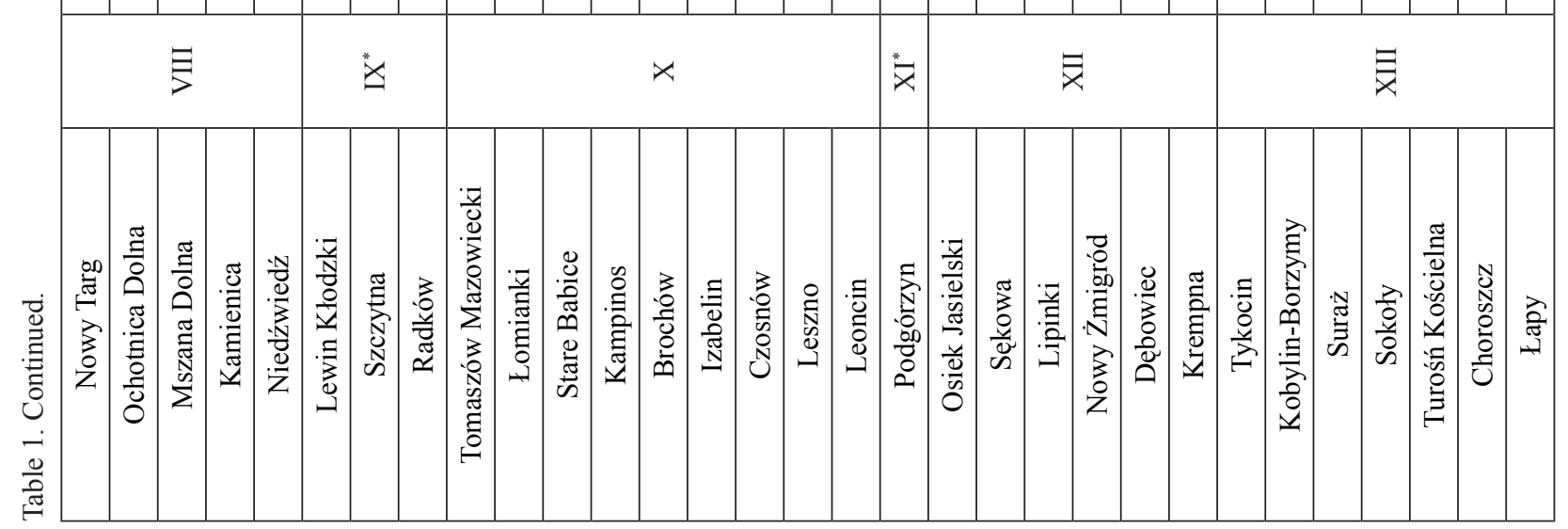


기 כ.

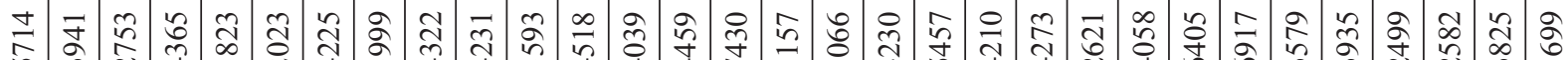

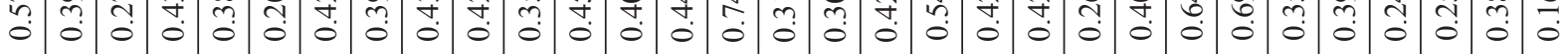

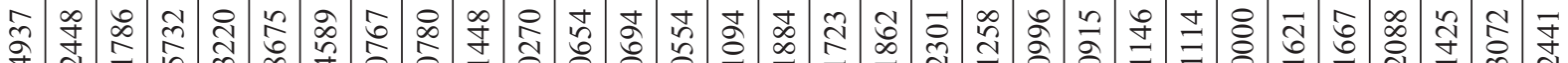

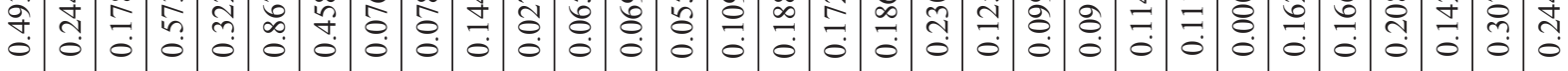

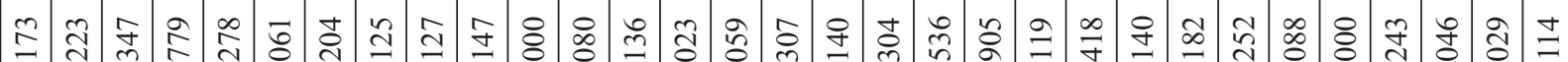
సี

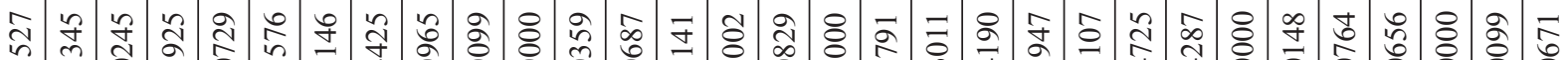

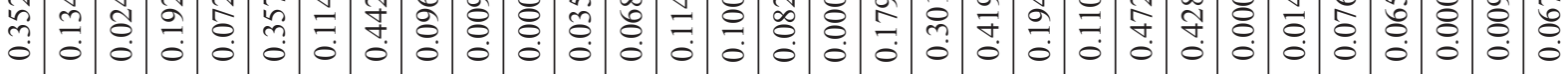

舟

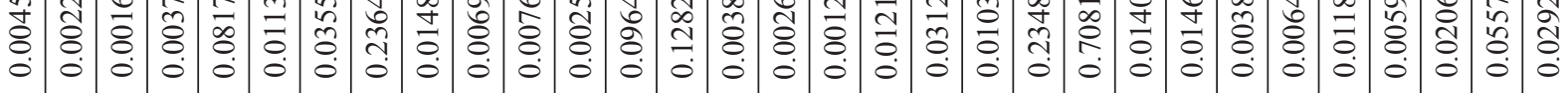

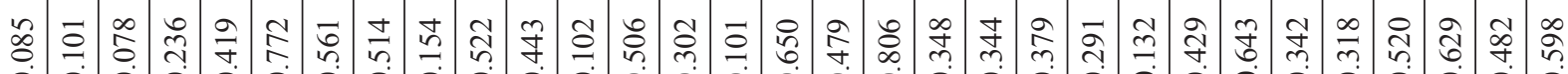

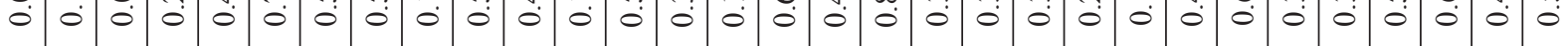

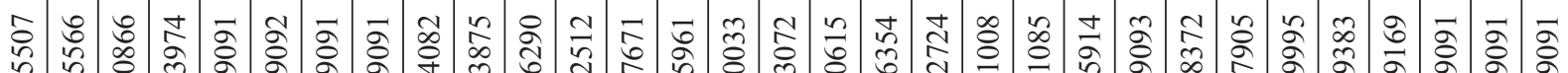
ڤ.

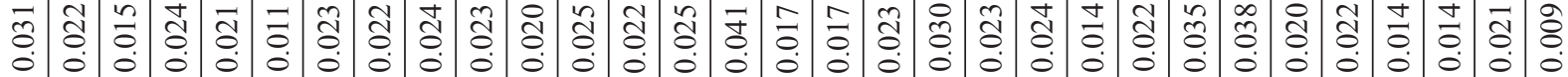

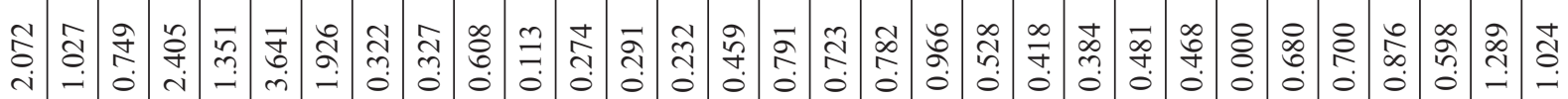

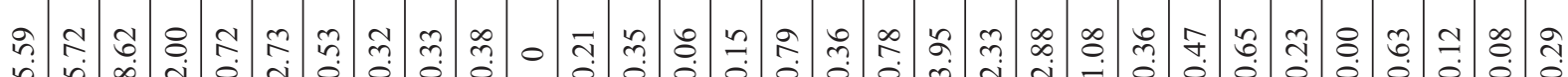

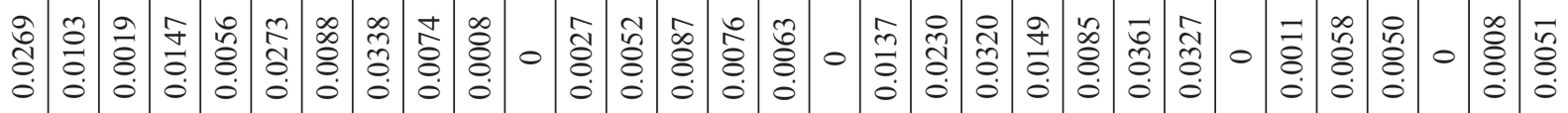

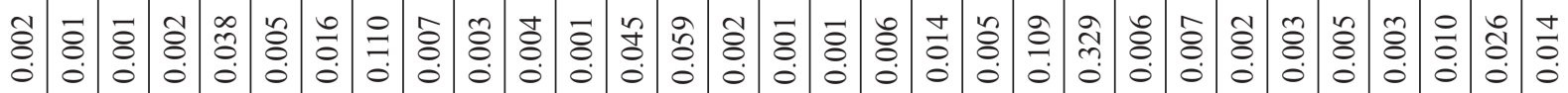
占

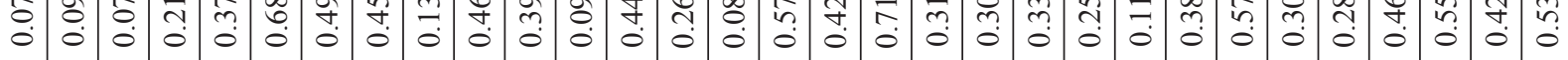

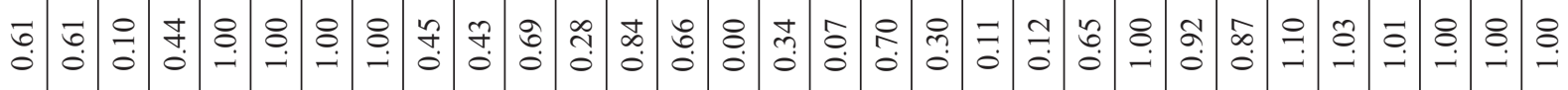

\begin{tabular}{|c|c|c|c|c|c|c|c|c|c|c|c|c|c|c|c|c|c|c|c|c|c|c|c|c|c|c|c|}
\hline \multicolumn{4}{|c|}{$\vec{x}$} & \multicolumn{4}{|c|}{$\vec{x}$} & \multicolumn{5}{|c|}{$\underset{x}{D}$} & \multicolumn{4}{|c|}{$\sum_{x}$} & \multicolumn{4}{|c|}{$\stackrel{*}{\stackrel{*}{x}}$} & \multicolumn{5}{|c|}{$\stackrel{x}{\ddot{x}}$} & \multicolumn{2}{|l|}{$x_{x}^{*}$} \\
\hline 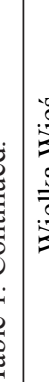 & 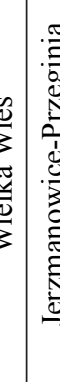 & 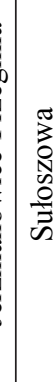 & $\frac{\frac{\pi}{\pi}}{\tilde{n}}$ & 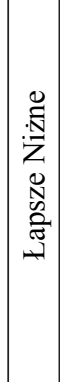 & 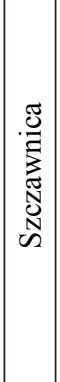 & 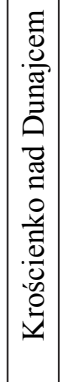 & 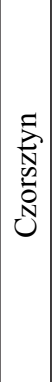 & 志 & 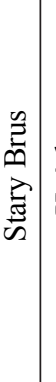 & 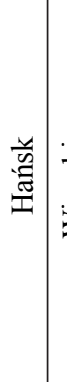 & 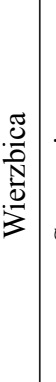 & 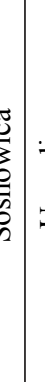 & 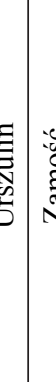 & 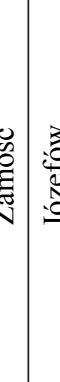 & 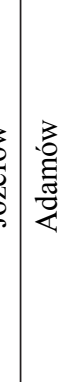 & 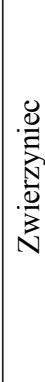 & 站 & $\begin{array}{l}\mathbb{8} \\
\stackrel{0}{0} \\
0 \\
\vdots 0 \\
0 \\
0\end{array}$ & $\frac{8}{3}$ & 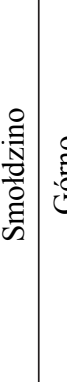 & 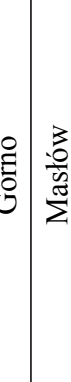 & 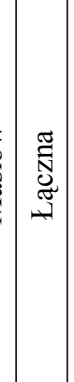 & 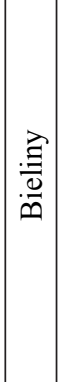 & 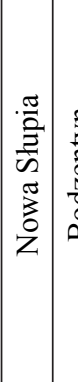 & 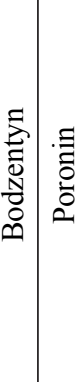 & 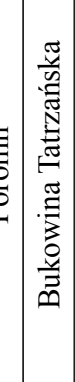 & 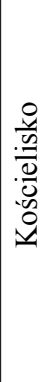 \\
\hline
\end{tabular}




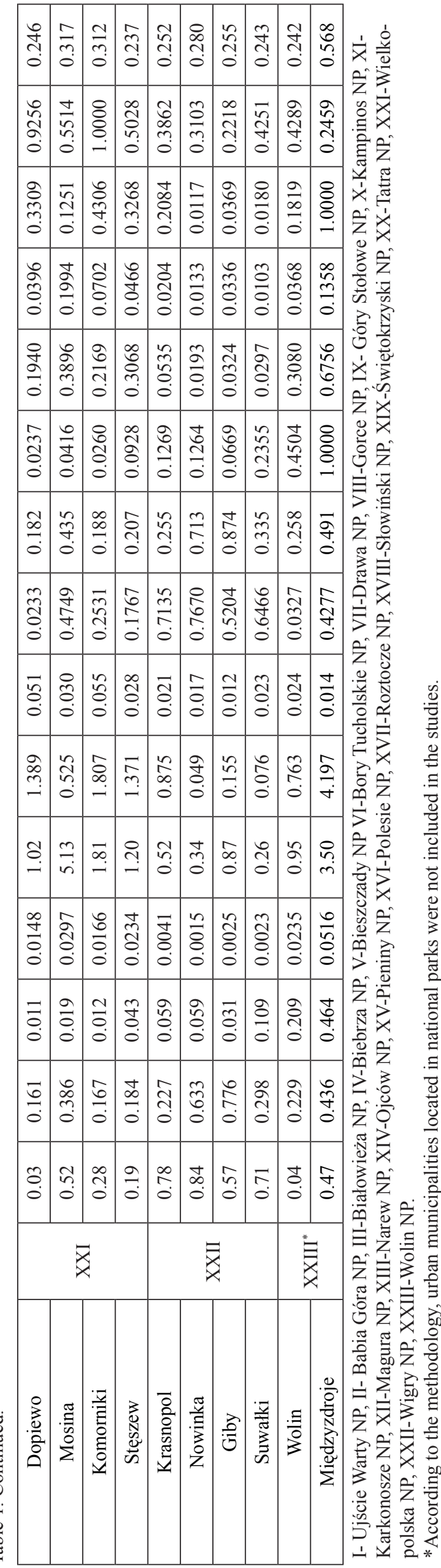

cases, the distribution is disproportionate. Municipalities with a medium tourism potential account for $78.6 \%$, while administrative units with a low TP are $16.5 \%$. The inverse situation can be observed in the case of the TA indicator. $17.5 \%$ of municipalities with medium tourism offer the most numerous units with small TA $(76.7 \%$. of the municipalities).

The municipalities take advantage of their natural resources and tourist virtues to various extents. $13.6 \%$ of the analysed administrative units have implemented their tourism potential very well, which confirms that it can be regarded as a mean for local economic development. Unfortunately, the number of municipalities where the existing conditions for leisure activities and recreation are not used in a satisfactory way is comparable $(15.5 \%)$. The most numerous group is comprised of local administrative units that use their tourism potential at a medium level (36.9\%). At the same time, the fact that a significant share of municipalities benefit well from the available resources (34\%) should be considered positive.

Five out of 17 municipalities (29\%) with a low tourism potential are able to use it efficiently. In the group of municipalities with a high tourism potential, $60 \%$ of units ( 3 out of 5 ) have taken the opportunity to develop tourism. Among the municipalities with a medium potential, tourist success can be noted in 50.6\% of cases (i.e., in 41 out of 81 administrative units).

There is no scientific literature and research data regarding the attractiveness and tourism potential of a complete set of municipalities located within the borders of Polish NPs. Studies on individual municipalities with the following characteristics usually show their high tourism attractiveness. However, the conducted research has proven that there is a high diversity between the analyzed units. The literature more often presents studies concerning the number of tourists and tourism space in NPs [31-25]. Therefore, assuming that the groups of municipalities partly located within the borders of a certain national park form a cohesive whole, the calculated indicators can be averaged arithmetically and become the basis of a simplified evaluation of the percentage tourism utilisation for particular national parks. The largest group of parks consists of the ones used 40-60\%, including: Bieszczady NP (41\%), Ujście Warty NP (43\%), Drawa NP (44\%), Świętokrzyski NP (45\%), Góry Stołowe NP (50\%), Gorce NP (51\%), Wielkopolska NP (52\%) Ojców NP (53\%), Wigry NP (56\%), and Bory Tucholskie NP (58\%). The group of national parks with a lower tourism utilisation level includes: Białowieża NP (27\%), Narwiański NP (27\%), Babia Góra NP (30\%), Magura NP (31\%), Biebrza NP $(33 \%)$, Polesie NP (35\%), and Kampinos NP (39\%). The highest level of tourism utilisation has been achieved in 4 parks: Pieniny NP (61\%), Roztocze NP (62\%), Wolin NP (72\%), and Słowiński NP (74\%).

The parks where tourism utilisation is assessed as being too intense per their natural values include Karkonosze NP (100\%) and Tatra NP (124\%). The 


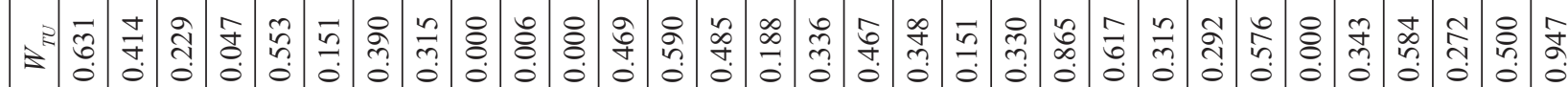

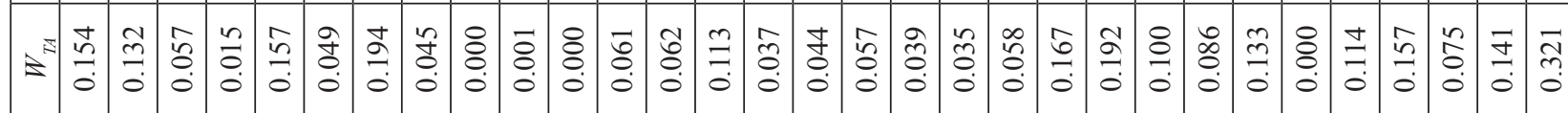

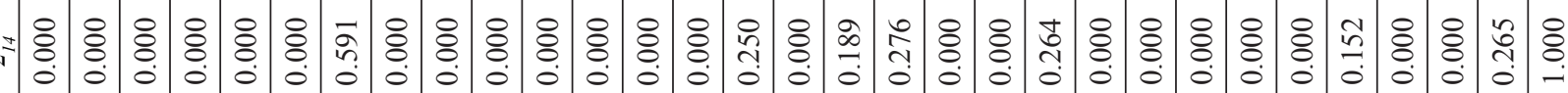

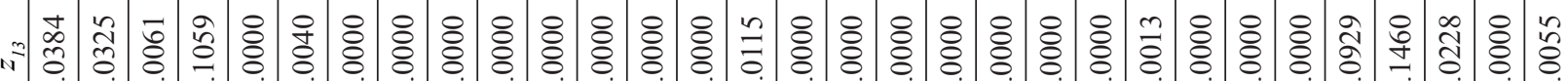

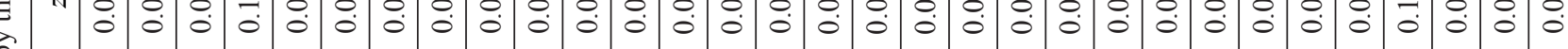
e

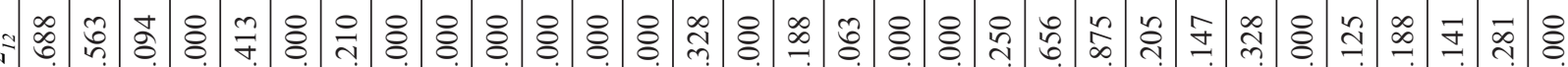
霊

के

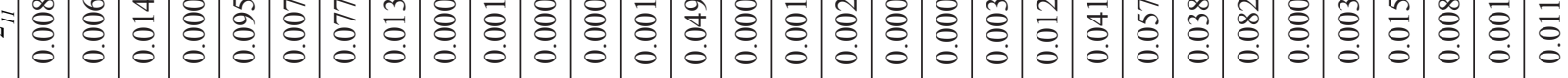

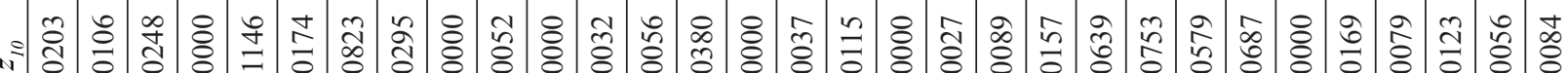

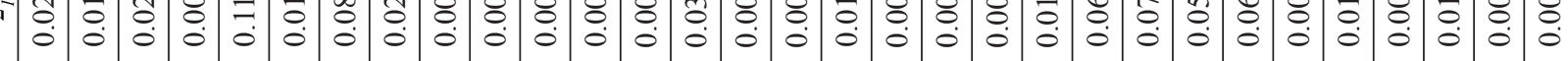

总

.:

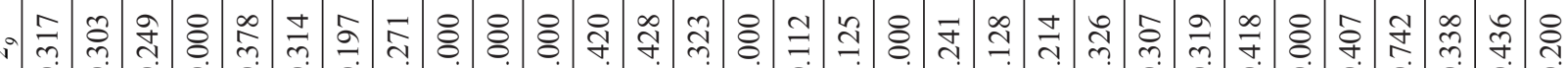
כ.

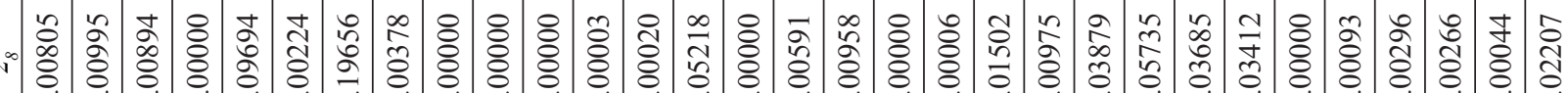

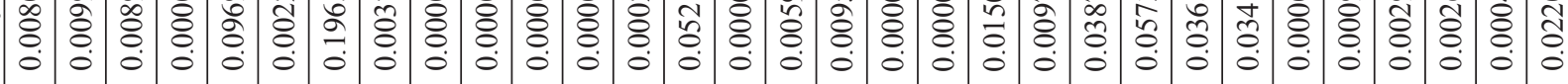

$=$ \&

$=$ పे

\#

:

$=\delta$ b

-

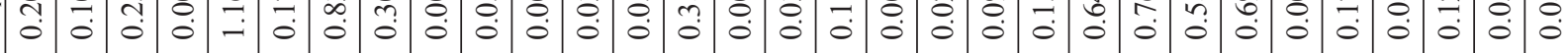

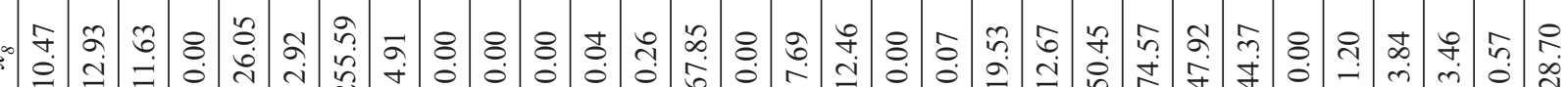
폴 


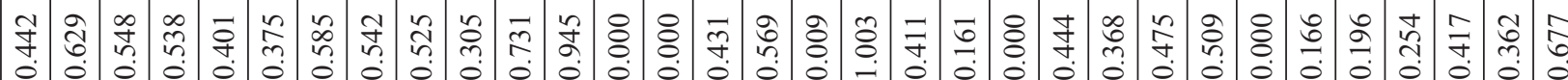

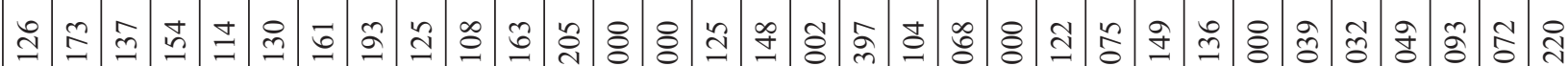

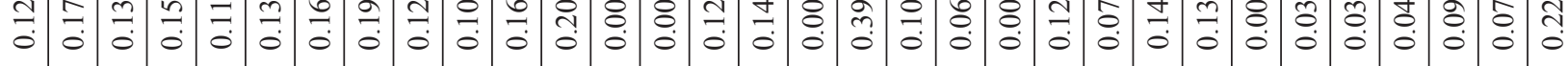

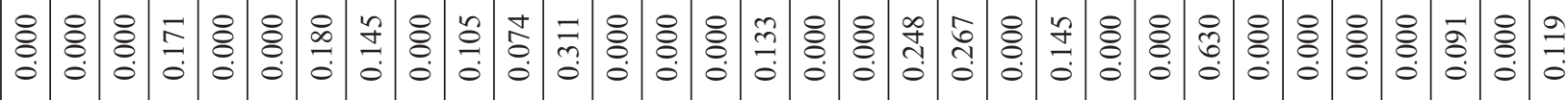
望

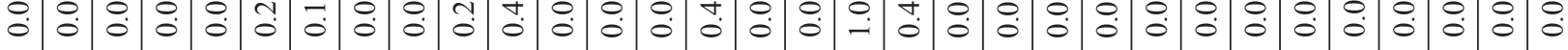

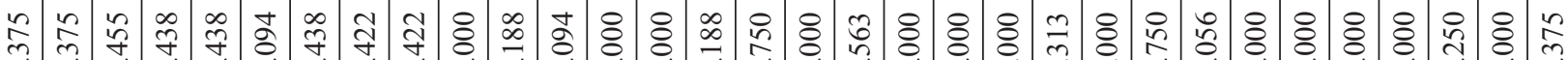

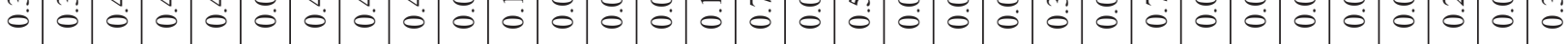

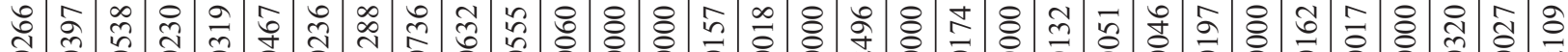

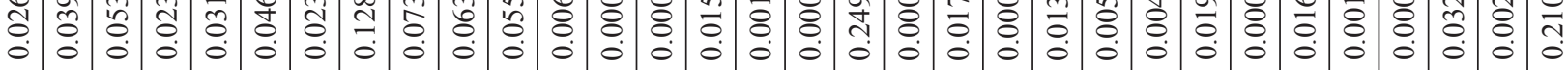

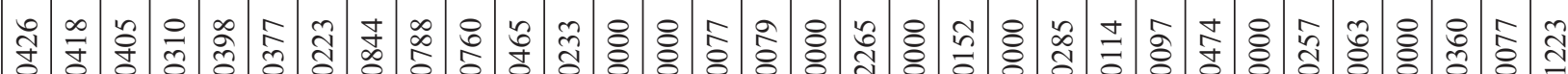

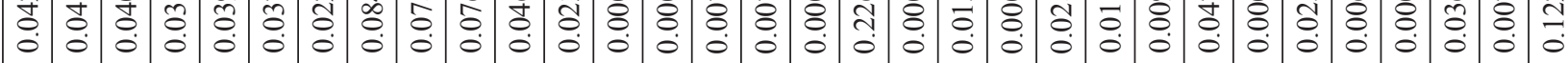

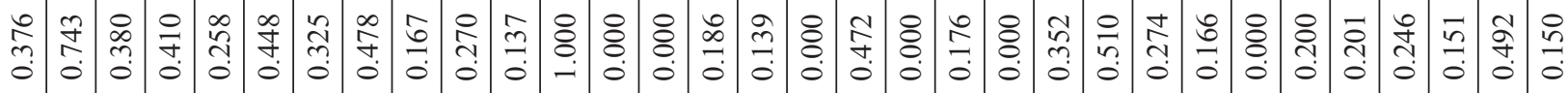

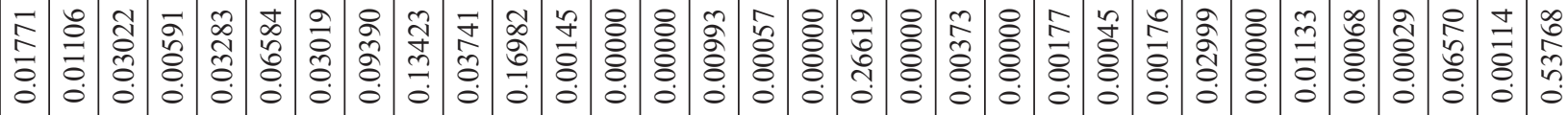

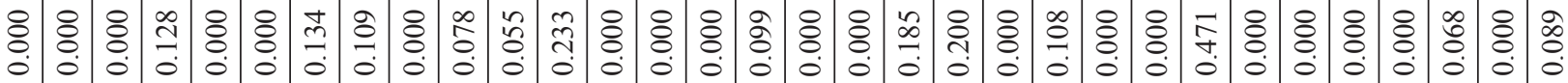

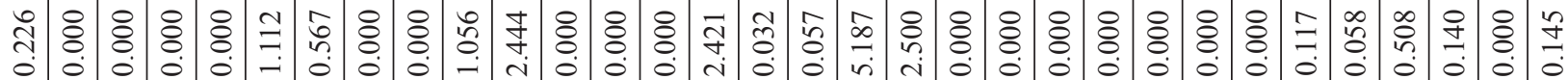

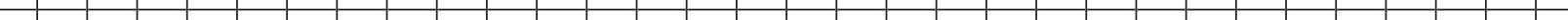

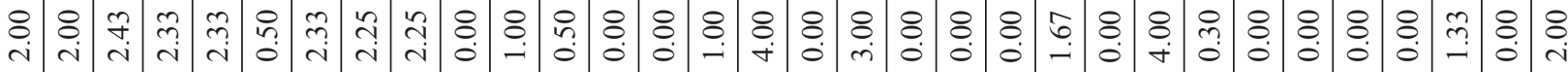

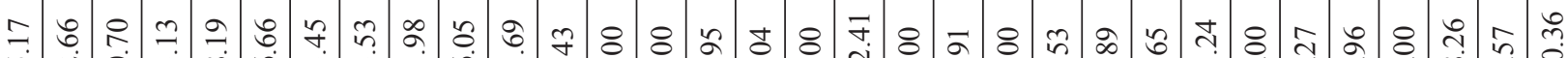

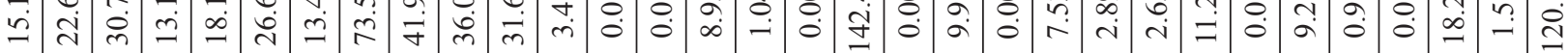

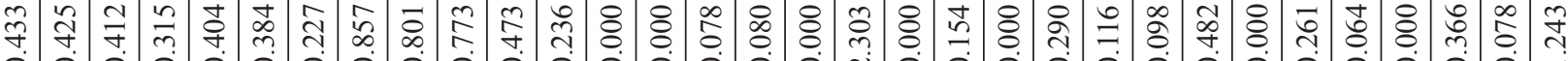

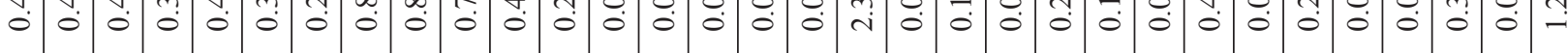
ঠ্লি

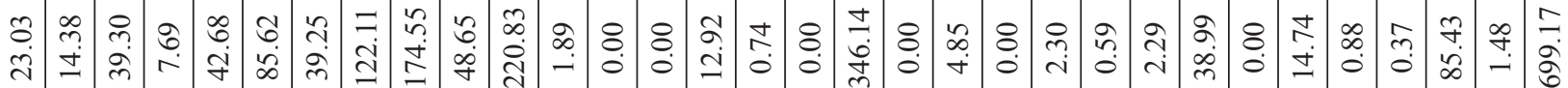

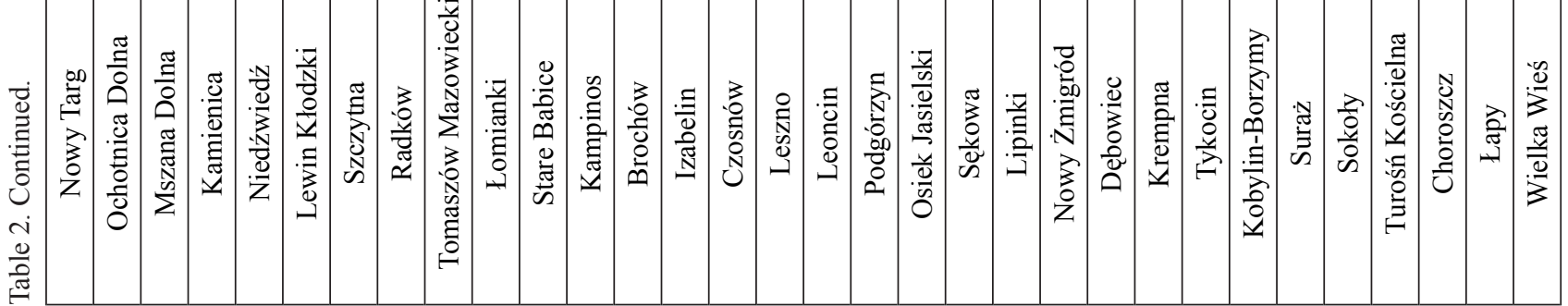




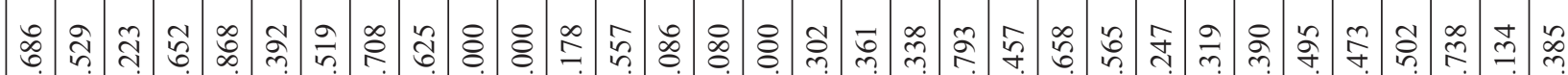
芫 닐

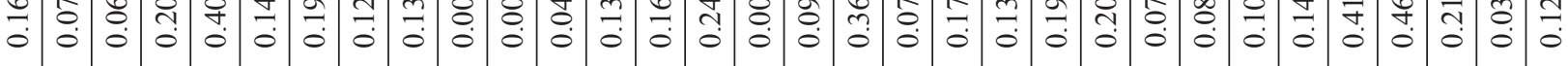

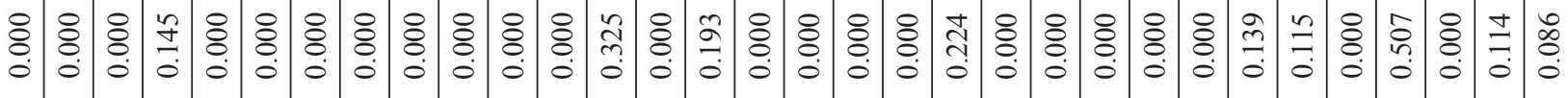
ఏ :

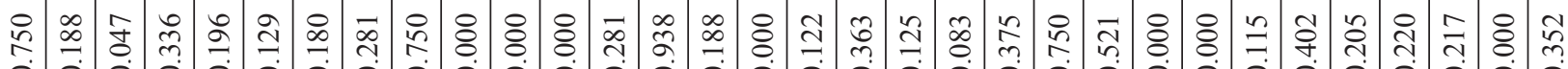

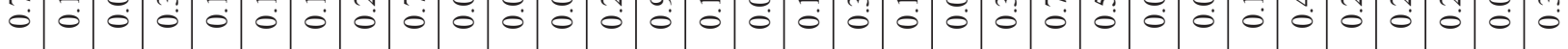

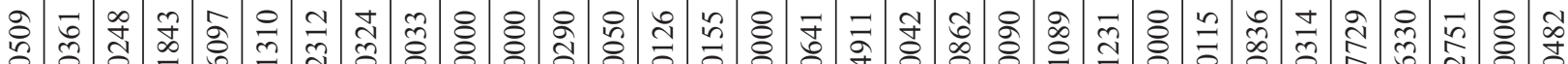

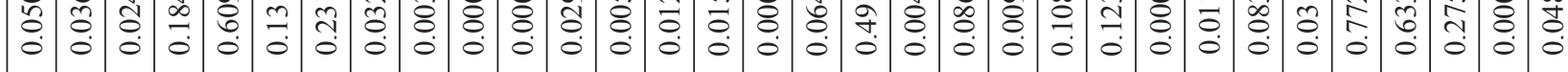

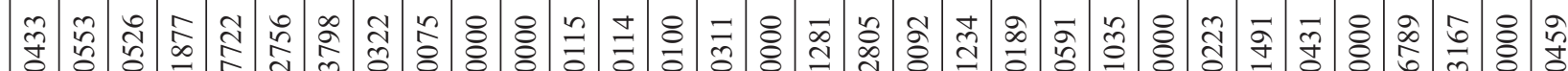

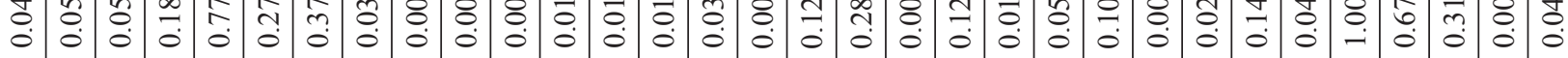
a

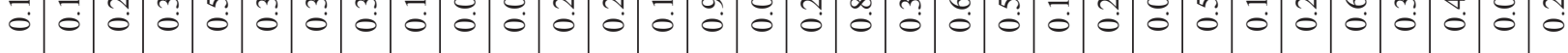

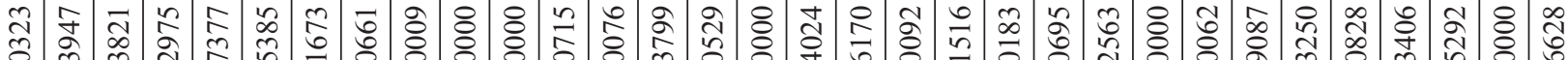
లి

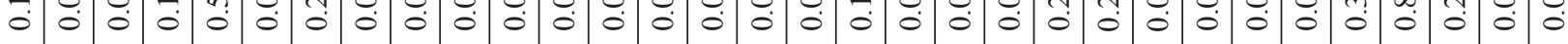

\&

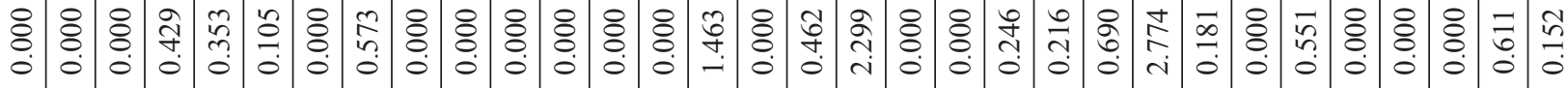

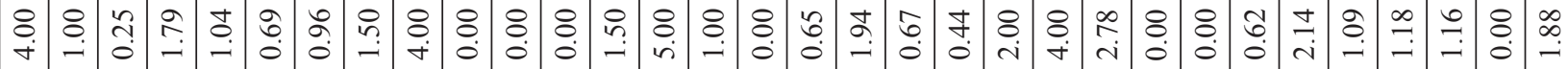

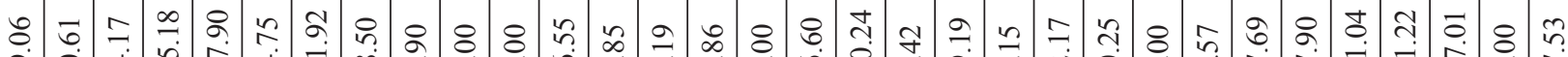

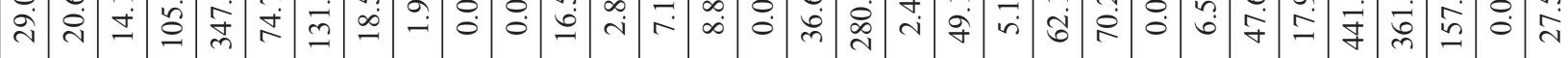

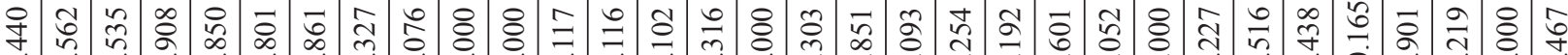

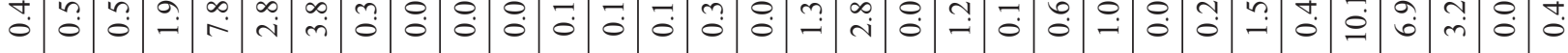

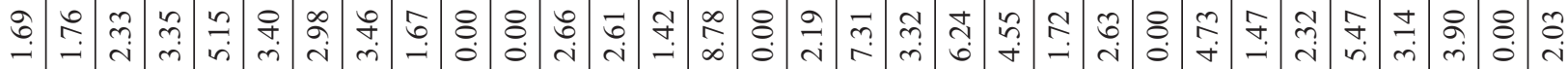

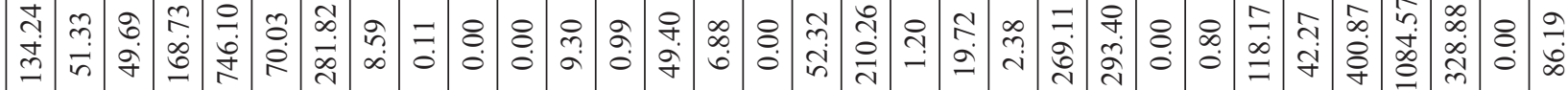

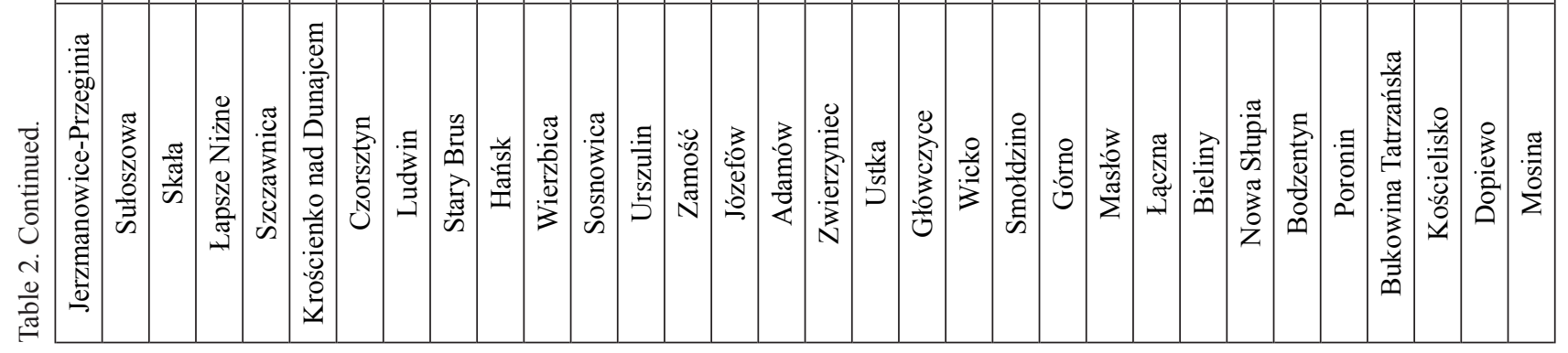




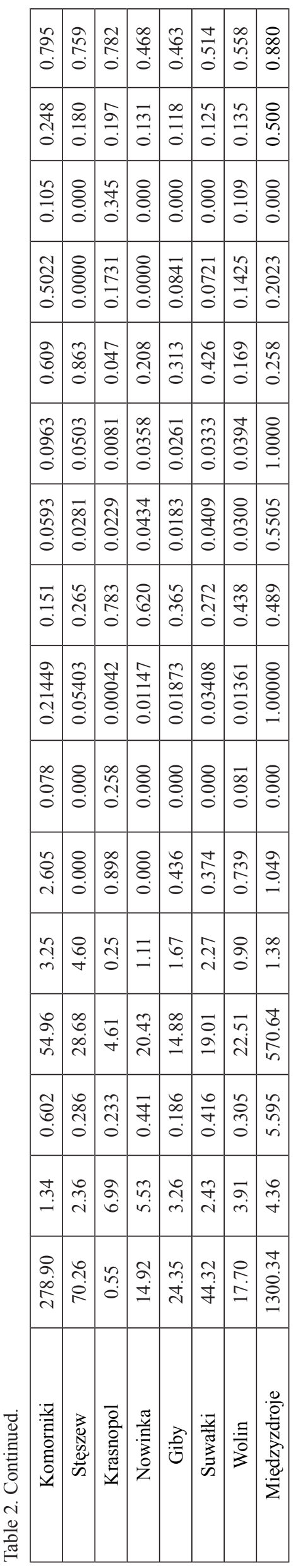

results obtained for the last group of parks may also indicate that their tourist absorbency has been significantly exceeded and became a crucial source of environmental problems. This kind of risk is confirmed by data from the Central Statistical Office on the number of tourists for 2014: Tatra NP 3.1 million and Karkonosze NP 2 million.

The obtained results concerning tourism utilisation of the parks were compared to the assessment of the parks carried out by Liszewski [20] and the ranking of the parks according to the number of tourists based on the data provided by the Central Statistical Office [21]. The verification confirmed that the results are highly consistent in the case of 11 national parks (48\%), quite consistent in the case of 9 parks (39\%) compared to the data from the Central Statistical Office, and for 10 parks (43\%) taking into consideration the outcome from Liszewski studies [20].

The reasons that some results for the parks differed from those presented in the study may be found in their location (Kampinoski, Roztoczański) or in the land-use structure (Białowieża, Bory Tucholskie). The studies clearly show that Kampinos, Wielkopolska, and partly Roztocze belong to the group of parks dominated by urban agglomerations, which means that they actually operate as suburban recreational areas for Warsaw, Poznań, and Lublin [26].

A rather different situation may be observed in the case of Białowieża and Bory Tucholskie, where intensive tourism growth is due to the high attractiveness and uniqueness of their nature and landscape values [28]. However, the dominance of protected forests in the land use structure and limited investment areas make the parks less attractive in terms of tourist accommodation. It should also be emphasized that there are frequent differences in the assessment of tourism in national parks carried out by survey research based on statistical data.

The applied survey method, having been verified for 103 administrative units, should be considered correct. It may be a useful tool for the analyses of the development in the study on the conditions and spatial development directions or development strategy, for the assessment of tourism utilization, planning for future investments in the fields of infrastructure, and tourist accommodation. However, it must be stated that there are three main factors that can to some extent negatively affect the picture of a municipality in terms of its potential for the development of tourism. These include:

- Lack of indicators reflecting the on-day (short term) tourism, which is very important for the municipalities located in the vicinity of large cities, where local residents use natural resources of a national park without the need for accommodation (e.g., Izabelin, Brochów).

- A decrease of variable normalization values for rural municipalities due to high values for urban-rural municipalities, especially for those that also cover tourist resorts (e.g., Międzyzdroje). 
Table 3. Quantitative distribution of types and groups of municipalities in terms of tourism potential (TP), attractiveness (TA), and tourism utilization rate $\mathrm{W}_{\mathrm{TU}}$ (by the authors).

\begin{tabular}{|c|c|c|c|c|c|c|c|c|c|c|c|c|c|}
\hline Group & \multicolumn{3}{|c|}{ I* } & \multicolumn{3}{|c|}{ II } & \multicolumn{3}{c|}{ III } & \multicolumn{3}{c|}{ IV } \\
\hline Type & A** & B & C & A & B & C & A & B & C & A & B & C & $\Sigma$ \\
\hline $1 * * *$ & 3 & 0 & 0 & 0 & 0 & 0 & 0 & 1 & 1 & 0 & 0 & 0 & 5 \\
\hline 2 & 3 & 7 & 0 & 0 & 10 & 21 & 0 & 0 & 30 & 0 & 0 & 10 & 81 \\
\hline 3 & 0 & 0 & 1 & 0 & 0 & 4 & 0 & 0 & 6 & 0 & 0 & 6 & 17 \\
\hline$\Sigma$ & 6 & 7 & 1 & 0 & 10 & 25 & 0 & 1 & 37 & 0 & 0 & 16 & 103 \\
\hline
\end{tabular}

*Group I - very good $\mathrm{W}_{\mathrm{TU}}$, Group II - good $\mathrm{W}_{\mathrm{TU}}$, Group III -medium $\mathrm{W}_{\mathrm{TU}}$, Group IV -low $\mathrm{W}_{\mathrm{TU}}$,

**Type A - high TA, Type B- medium TA, Type C - low TA;

***Type 1 - high TP, Type 2 - medium TP, Type 3 - low T

- Isolated cases of "no data" for tourism accommodation in the local data bank, which causes a "lack of tourism attractiveness" according to the methodology applied.

In conclusion, the analyses carried out in most cases confirmed that the municipalities located in the impact area of national parks do not fully realise their potential, which is related to the natural environment. Moreover, there is also a significant diversification of the administrative units in terms of the use of the available resources, also within particular national parks.

\section{References}

1. VISIT SCOTLAND. Scotland visitor Survey 2015 and 2016. Research by TNS for Insight Department, 2017. Available on line: www.visitscotland.org/pdf/ ShortVersionScotlandVisitorSurvey2015-16-250417.pdf (accessed on 20.04.2017).

2. BALMFORD A., GREEN J.M.H., ANDERSON M., BERESFORD J., HUANG CH., NAIDOO R., WALPOLOE M., MANICA A. Walk on the Wild Side: Estimating the global magnitude of visits to protected areas. PLOS Biol 13(2): 2015 Available on line: https://doi.org/10.1371/ journal.pbio.10020742015 (accessed on 20.04.2017).

3. GRAHAM C., BARROW B.A. Tourist and Future National Parks in Scotland. How more National Parks could grow the visitor economy of Scotland. SCNP. 11, 2016.

4. STOKKE, KB, BJORNSTAD, K, CLEMETSEN, M, HAUKELAND J.V. Recreation and tourism -sociocultural and socioeconomic impacts on protected areas in Norway". 2011. Available on line: www.iscaralpinresearch.org (accessed on 20.04.2017).

5. LINDBERG K., DENSTADLI J.M. Impact of National Park Visitation on Rural Economies and Government Revenue in Queensland: Examples of Girraween, Eungella, Daintree and Carnarvon. Australia: CRC for Sustainable Tourism. 82, 2004

6. GRAJA S. Przestrzeń turystyczna parków narodowych: przykład Parku Narodowego "Ujście Warty". Unpublished Doctoral Thesis (typescript), Uniwersytet Łódzki. Wydział Nauk Geograficznych, 2007.

7. OLACZEK R. Między swobodą a zakazem - o turystycznym korzystaniu $\mathrm{z}$ obszarów chronionych.
Turystyka zrównoważona i ekoturystyka. Polskie Towarzystwo Turystyczno-Krajoznawcze, Warszawa, $15,2008$.

8. MOISEY R.N. The economics of tourism in national parks and protected areas. Tourism in national parks and protected areas: planning and management; Eagles P. F. J. and McCool S.F. Eds., CABI Publishing, Wallingford, UK. 235, 2002.

9. MAYER M., MÜLLER M., WOLTERING M., ARNEGGER J., JOB H. The economic impact of tourism in six German national parks. Landscape and Urban Planning. Elsevier. 73, 2010.

10. IUCN. Tourism and Visitor Management in Protected Areas Guidelines for sustainability. 266, 2014. Available on line: https://iucn.oscar.ncsu.edu/mediawiki/images/3/3a/ Sustainable_Tourism_BPG_Full_Review_Copy_for_ WPC14_v2.pdf (accessed on 20.04.2017).

11. ZAWILIŃSKA B., MIKA M. National parks and local development in Poland: a municipal perspective. Human Geographies - Journal of Studies and Research in Human Geography 7 (1), 43, 2013

12. MIKA M., ZAWLIŃSKA B., PAWLUSIŃSKI R. Exploring the economic impact of national parks on the local economy. Functional approach in the context of Poland's transition economy. Human Geographies Journal of Studies and Research in Human Geography 10 (1), 7, 2016.

13. PUHAKKA R. Increasing role of tourism in Finnish national parks. Fennia 186: 1, Helsinki. 47, 2008.

14. GETZNER M. The Economic Impact of National Parks: the Perception of Key Actors in Austrian National Parks. International Journal of Sustainable Development, 6 (2), $183,2003$.

15. CEBALLOS-LASCURÁIN H., MCNEELY J.A., THORSELL J.W. Guidelines: development of national parks and protected areas for tourism. IUCN. Tourism and the environment/WTO. 52, 1992.

16. SWEDISH ENVIRONMENTAL PROTECTION AGENCY. Protect, preserve, present: a programme for better use and management of protected areas, 2005-2015. Report 5483. Swedish Environmental Protection Agency, Stockholm, Sweden, 2004. Available on line: http://www. naturvardsverket.se/Om-Naturvardsverket/Publikationer/ ISBN/5400/91-620-5483-X/ (accessed on 20.04.2017).

17. NEUVONEN M., POUTA E., PUUSTINEN J., SIEVÄNEN T. Visits to national parks: Effects of park characteristics and spatial demand. Journal for Nature Conservation, 18, Elsevier. 224, 2010. 
18. JUUTINENA A., MITANID Y., MÄNTYMAAC E., SHOJIE Y., PIRKKO SIIKAMÄKIF P., SVENTOA R. Combining ecological and recreational aspects in national park management: A choice experiment application. Ecological Economics 70 (6), Elsevier. 231, 2011

19. RUSIELIK R., ZBARASZEWSKI W. The efficiency of scientific and tourism activity of Polish National Parks with use DEA method. Economic and Environmental Studies. 14 (3) (31/2014), 283, 2014.

20. LISZEWSKI S. Przestrzeń turystyczna parków narodowych w Polsce. Gospodarka i przestrzeń. (DOMAŃSKI B. KUREK W. - Eds.). Kraków, 187, 2009.

21. Central Statistical Office. Environment 2015 Available on line: http://stat.gov.pl/obszary-tematyczne/srodowiskoenergia/srodowisko/ochrona-srodowiska-2015,1,16.html (accessed on 20.04.2017).

22. PODAWCA K. Planowanie przestrzenne gmin a zagospodarowanie przestrzenne parków narodowych, Acta Scientiarum Polonorum. Architectura, 5 (2), 97, 2006.

23. Local Data Bank. Available on line: https://bdl.stat.gov.pl/ BDL/start (accessed on 20.04.2017).

24. BORYS T. Wskaźniki zrównoważonego rozwoju. Ekonomia i Środowisko, Wyd. Warszawa-Białystok, 70 2005.

25. CHUDY-HYSKI D. Wybrane aspekty turystycznego kierunku rozwoju górskich obszarów wiejskich. Infrastruktura i Ekologia Terenów Wiejskich, Komisja Technicznej Infrastruktury Wsi PAN, Kraków, 311, 2009.

26. WŁODARCZYK B., Przestrzeń turystyczna. Istota, koncepcje, determinanty rozwoju, Wyd. Uniwersytetu Łódzkiego, Łódź, 269, 2009.

27. BRZEZIŃSKA-WÓJCIK T., ŚWIECA A., Czynniki kształtujące przestrzeń turystyczną Wyniosłości Giełczewskiej (środkowowschodnia Polska). Przestrzeń Turystyczna -czynniki, różnorodność, zmiany (DURYDIWKA M., DUDA-GROMADA K. - Eds.) Uniwersytet Warszawski, Wydział Geografii i Studiów Regionalnych, Warszawa, 279, 2011.
28. ZIARNICKA-WOJTASZEK A., ZAWORA T. Wybrane metody oceny atrakcyjności agroturystycznej terenów wiejskich, Infrastruktura i Ekologia Terenów Wiejskich, Nr 2/2011, PAN, Oddział w Krakowie, 235, 2011.

29. STRAHL D. Propozycja konstrukcji miary syntetycznej. Przegląd Statystyczny, z. 2, 205, 1978.

30. WALESIAK M. Przegląd formuł normalizacji wartości zmiennych oraz ich własności w statystycznej analizie wielowymiarowej. Taksonomia. Przegląd Statystyczny 4, 363, 2014.

31. CZARNECKI K. Atrakcyjność turystyczna i ruch turystyczny w Parkach Narodowych Karpat Zachodnich - analiza porównawcza. Środowisko społecznoprzyrodnicze a aktywność fizyczna człowieka (KAISER A., SOKOŁOWSKI M.- Eds.), Wielkopolska Wyższa Szkoła Turystyki i Zarządzania, Poznań, 435, 2010.

32. PARTYKA J. Ruch turystyczny w Polskich Parkach Narodowych. Folia Turistica, Turystyka i Ekologia 22, 9, 2010.

33. PRÓSZYŃSKA-BORDAS H. Przestrzeń turystyczna parków narodowych a źródła emisji ruchu turystycznego. Przestrzeń turystyczna - czynniki, różnorodność, zmiany (DURYDIWKA M., DUDA-GROMADA K. - Eds.), Uniwersytet Warszawski, Wydział Geografii i Studiów Regionalnych, Warszawa, 341, 2011.

34. HIBNER J. Struktura ruchu turystycznego w polskich górskich parkach narodowych należących do sieci „Człowiek i Biosfera”. Współczesne problemy i kierunki badawcze w geografii (KRĄŻ P., HIBNER J., KOJ J., BALON J. - Eds.), Instytut Geografii i Gospodarki Przestrzennej UJ, Kraków, 73, 2013.

35. CZARNECKI K. Atrakcyjność turystyczna i ruch turystyczny w parkach narodowych województwa podlaskiego, Zeszyty Naukowe SGGW, Ekonomika i Organizacja Gospodarki Żywnościowej, no 73, Wyd. SGGW, Warszawa, 165, 2009. 
